\title{
A case of primary hydatid cyst in the thyroid gland
}

\author{
Mehmet Kadir Bartın', Eyüp Murat Yılmaz', Harun Arslan², Arzu Esen Tekeli³, Semra Karataș³
}

\begin{tabular}{ll}
\hline ABSTRACT & $\begin{array}{l}\text { Hydatid disease is a significant infestation caused by the tapeworm Echinococcus granulosus. Primary hydatid dis- } \\
\text { ease of the head and neck without systemic involvement is quite rare in endemic regions. } \\
\text { Keywords: Hydatid cyst, thyroid gland, ultrasound }\end{array}$
\end{tabular}

\section{INTRODUCTION}

Hydatid cyst is a disease caused by the echinococcus family, which is common in Turkey and the world. It has a high incidence rate in regions with a mild climate such as Mediterranean countries, Middle East, South America, New Zealand, Australia and Southeast Asia. Hydatid cyst develops most often in the liver $(65 \%)$ and lungs $(25 \%)$ in human beings. The incidence of hydatid cysts in the thyroid gland was claimed to be $0.5-1 \%$ in Turkey. Hydatid cyst involvement of the thyroid is rather rare and may be confused with malignancy (1). There are approximately 160 thyroid hydatid cases reported in the literature (2). In this case report, we present a hydatid disease of the thyroid, a rarely seen case.

\section{CASE PRESENTATION}

A thirty-two-year-old female patient presented to the general surgery outpatient clinic of our hospital with complaints of a palpable and growing mass in the neck for approximately 6 months and hoarseness. On the patient's physical examination a mobile, soft nodule, approximately $3 \times 2 \mathrm{~cm}$ in size, which did not invade the surrounding tissues, was palpated in the right lobe of thyroid (Figure 1). No lymphadenopathies were identified in the neck. Other system examinations were normal. The thyroid ultrasonography (US) revealed diffuse enlargement in both thyroid lobes, and multiple nodules in both lobes with the largest being on the right side at a size of $36 \times 24 \mathrm{~mm}$ (Figure 2). The hydatid cyst on the right thyroid lobe pushed the common carotid artery and jugular vein to the right, and the trachea and oesophagus slightly to the left. No other cystic lesions were encountered in the cranial, thoracic and abdominal cavities. The hemagglutination test was positive for hydatid cyst. Her medical history and other physical examination findings were unremarkable. The results of blood tests (whole blood count, blood biochemistry) and thyroid function tests were normal. The patient was presumed to have multinodular goitre and was scheduled for surgery. She underwent bilateral total thyroidectomy. Peroperatively, daughter cysts were observed within the cyst (Figure 3a, b). No intraoperative and postoperative complications developed and the patient was discharged on postoperative day 2 . The postoperative histopathological examination, reported the cyst pertaining to the thyroid tissue as hydatid disease. The patient was administered $400 \mathrm{mg} /$ day albendazole treatment for 2 months postoperatively. No other focus of hydatid cyst was encountered. The patient is being followed-up without any recurrence.

\section{DISCUSSION}

Hydatid cyst remains to be a significant health problem, especially in regions where echinococcus is endemic. This disease mostly develops due to E. granulosus, and rarely due to E. Multilocularis, with the primary hosts being dogs, and intermediate hosts including cattle, sheep, pigs and human beings (3). The parasite egg that enters the body of an intermediate host is hatched in small intestine and reaches the liver or lung through the portal vein or lymphatic system, thereby creating cystic lesions (4). After that, they may pass through hepatic sinusoids or pulmonary capillary barriers, gain access into the systemic circulation, and invade any organ. They are mostly located in the liver and lungs; while the brain, bones, spleen, kidneys, pancreas, heart and muscles may also be involved. Hydatid disease may rarely involve the thyroid gland (5). Thyroid gland involvement is seen in only $1-2 \%$ of those with hydatid disease of the liver or the lung (6). Our case did not have abdominal, thoracic or cerebral involvement. The majority of hydatid cysts do not result in any symptoms. The disease is generally asymptomatic; however, clinical symptoms may develop depending on the dimensions, location or pressure caused by the growing cyst (5). In our case, there were no symptoms other than a painless, mobile swelling in the right lobe of thyroid gland. In echinococcosis cases, the diagnosis is made on the basis of patient history, physical examination, radiological imaging methods, serological tests and aspiration (5). The radiological diagnostic methods generally include US, computerized tomography $(\mathrm{CT})$ and magnetic resonance $(\mathrm{MR})$ imaging $(7,8)$. Serological tests include indirect hemagglutinati- 


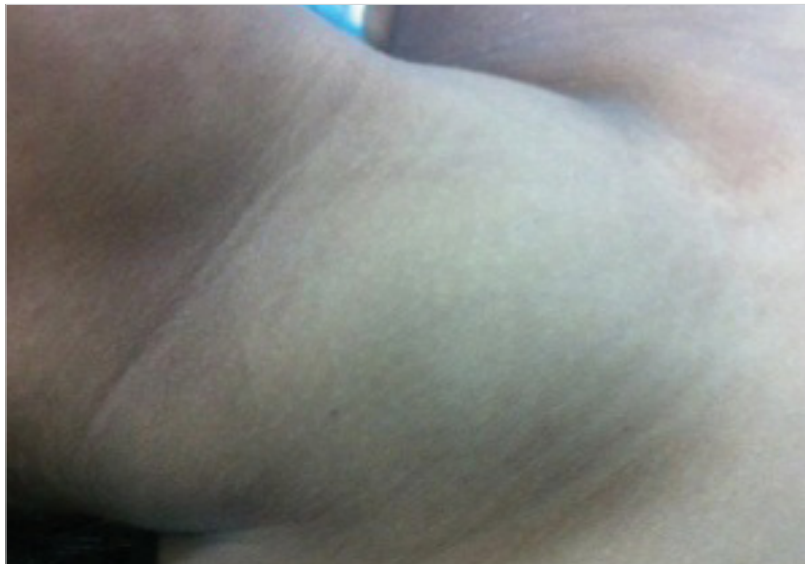

Figure 1. Preoperative view of the patient

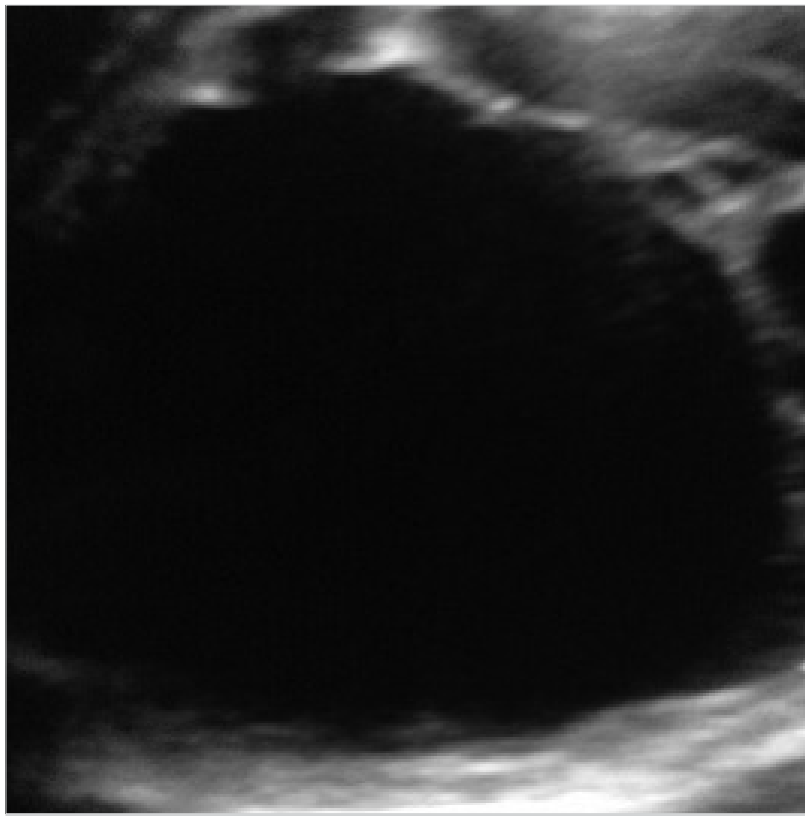

Figure 2. Hydatid cyst with septations in the right thyroid lobe

on, latex agglutination, ELISA and immune electrophoresis. In our case, an indirect hemagglutination test was conducted and the result was found to be positive. Even though they may result in false positive or false negative results, serological tests are used commonly to verify the diagnosis (9). The imaging methods are more sensitive than serological tests especially in unusual cyst locations, and identification of germinative membranes or germinal vesicles while serological tests are negative should be assessed in favour of echinococcosis. Since there are no effective medical treatments available, the most efficient treatment for hydatid cyst remains to be surgical excision. The aim of surgery is to prevent the spread of its contents and to remove the cyst in its entirety. If surgical treatment is not possible due to the patient's overall condition, treatment with mebendazole or albendazole, that are associated with unpredictable results and side effects, may be attempted. A long-term follow-up is required (10). Anti-parasitic medications seem to play a role in eliminating live parasites and in preventing contamination by cyst contents during surgery, rather than ensuring a full recovery. Treatment of hydatid cyst of the thyroid is excision, as is the case for all hydatid cysts in the body (11). In our case, we performed bilateral total thyroidectomy. No complications developed following surgery.
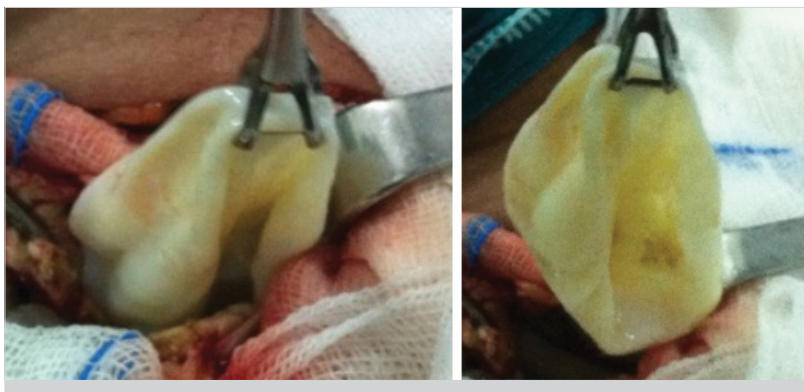

Figure 3. a,b. The cyst

\section{CONCLUSION}

Hydatid cysts should be kept in mind as part of differential diagnosis of cystic masses in the head and neck region, even in the absence of a primary hydatid disease location.

Informed Consent: Written informed consent was obtained from patient who participated in this case.

Peer-review: Externally peer-reviewed.

Author Contributions: Concept - E.M.Y.; Design - E.M.Y., H.A.; Supervision - M.K.B.; Funding - E.M.Y., A.E.T., S.K.; Materials - H.A., A.E.T.; Data Collection and/or Processing - H.A., M.K.B.; Analysis and/or Interpretation - E.M.Y., H.A., A.E.T.; Literature Review - E.M.Y., M.K.B., H.A.; Writer - E.M.Y.; Critical Review - A.E.T., S.K.

Conflict of Interest: No conflict of interest was declared by the authors.

Financial Disclosure: The authors declared that this study has received no financial support.

\section{REFERENCES}

1. Chetty R, Crovve P, Cant P. An unusal thyroid cyst. S Afr J Surg 1991; 29: 158-159.

2. Özerkan E, Gürçınar M, Sarıoğlu B, Aydınlıoğlu H. A case of cystic echinococcosis in thyroid gland: a very rare localisation of echinococcosis infection. Turk J Endocrinol Metabol 1999; 4: 181-183.

3. Dahniya MH, Hanna RM, Ashebu S, Muhtaseb SA, el-Beltagi A, Badr $S$, et al. The imaging appearances of hydatid disease at some unusual sites. Br J Radiol 2001; 74: 283-289. [CrossRef]

4. Ezer A, Nursal TZ, Moray G, Yildirirn S, Karakayali F, Noyın T, et al. Surgical treatment of liver hydatid cysts. HPB (Oxford) 2006; 8: 3842. [CrossRef]

5. Milicevic M, Saidi F, Sayek I. Karaciğer kist hidatiği. In: Sayek I, editor. Temel cerrahi. $3^{\text {rd }}$ ed. Ankara: Güneş Tıp Kitapevi; 2004. s. 1317-1324.

6. Lieberman PL. Anaphylaxis. In: Adkinson NF Jr, Bochner BS, Busse WW, Holgate ST, Lemanske RF Jr, Simons FER, ed. Middleton's allergy: principles and practice. $7^{\text {th }}$ ed China, Elsevier, 2009: 10271049. [CrossRef]

7. Turgut S, Ensari S, Katirci H, Çelikkanat S. Rare otolaryngologic presentation of Hydatid cyst. Otolaryngol Head Neck Surg 1997; 117: 418-421. [CrossRef]

8. Jain SK, Jamdade PT, Muneshwar SS, Ambulgekar VK, Panzade SM. Hydatid cyst of thyroid: an unusual cause of stridor. Ind J Otolaryngol Head Neck Surg 2005; 57: 80-81.

9. Bouckaert NM, Raubenheimer EJ, Jacobs FJ. Maxillofacial hydatid cysts. Oral Surg Med Oral Pathol Radiol Endod 2000; 89: 338-342. [CrossRef]

10. Sahni JK, Jain M, Bajaj Y, Kumar V, Jain A. Submandibular hydatid cyst caused by Echinococcus oligarthrus. J Laryngol Otol 2000; 114: 473-476. [CrossRef]

11 Smego RA Jr, Sebanego P. Treatment options for hepatic cystic echinococcosis. Int J Infect Dis 2005; 9: 69-76. [CrossRef] 